\title{
APBA1 Gene
}

National Cancer Institute

\section{Source}

National Cancer Institute. APBA1 Gene. NCI Thesaurus. Code C104827.

This gene is involved in synaptic vesicle exocytosis. 